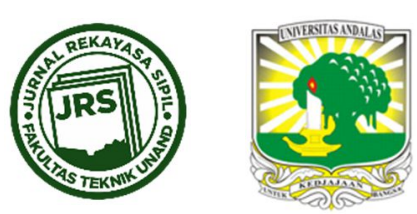

\title{
ANALISIS PENINGKATAN NILAI CBR TANAH RAWA MENGGUNAKAN CAMPURAN PETRASOIL DAN KAPUR
}

\author{
INDRAYANI $^{{ }^{*}}$, ANDI HERIUS ${ }^{1}$, DARMA PRABUDI ${ }^{1}$, ADE S. PRATAMA ${ }^{1}$, PUTRA \\ NANDA $^{1}$, NURMAN FERNANDO ${ }^{1}$
}

${ }^{1}$ Jurusan Teknik Sipil, Politeknik Negeri Sriwijaya, Palembang, Indonesia

*Corresponding author: $₫$ iin_indrayani@polsri.ac.id

Naskah diterima : 21 September 2020. Disetujui: 4 Februari 2021

\begin{abstract}
ABSTRAK
Daerah rawa di Kabupaten Banyuasin di Provinsi Sumsel (Sumatera Selatan) merupakan daerah yang rawan genangan air yang perlu mendapat perhatian khusus. Kawasan ini memiliki potensi sumber daya lahan yang besar dari sektor pertanian, perkebunan peternakan dan budidaya perikanan. Pada saat terjadi intensitas curah hujan yang tinggi, akses jalan daerah ini rusak parah disebabkan lemahnya daya dukung tanah, pada lapis tanah dasar (subgrade) tanahnya memiliki kohesifitas tinggi/ tanah lunak. Penggunaan bahan-bahan stabilizing agent, dapat memperbaiki sifat mekanik dari tanah lunak dan meningkatkan daya dukungnya. Penelitian ini menggunakan metode stabilisasi kimiawi dengan berbagai variasi campuran additive petrasoil dan kapur, yang mana penelitian sebelumnya yang hanya menggunakan bahan additive petrasoil menyebabkan penurunan terhadap nilai CBR tanah, namun pada beberapa proyek jalan petrasoil masih terus digunakan dengan campuran bahan lain, sehingga perlu dilakukan penelitian ini dengan mencampurkan additive petrasoil bahan tambah lain seperti kapur untuk mendapatkan pengaruh petrasoil terhadap peningkatan nilai CBR. Persentase campuran kapur adalah 10\%, 15\%, 20\% dengan tambahan petrasoil sebesar $1 \mathrm{~kg}$ yang dilarutkan dalam 1000 liter air. Dari hasil pengujian didapatkan penambahan petrasoil dan kapur sebagai bahan tambah pada tanah rawa dengan klasifikasi tanah lempung dapat meningkatkan nilai CBR dari $1,55 \%$ pada keadaan tanah asli menjadi 7,88\% pada kondisi tanah yang distabilisasi menggunakan petrasoil dan kapur $20 \%$.
\end{abstract}

Kata kunci : Nilai CBR; Petrasoil, Kapur; Tanah Lempung

\section{LATAR BELAKANG}

Sejalan dengan kebijakan Pemerintah Indonesia tentang pelaksanaan percepatan pembangunan, peranan infrastruktur jalan di Kabupaten Banyuasin semakin penting keberadaannya dari tahun ke tahun, dimana infratstruktur tersebut bertujuan untuk mengejar ketertinggalan dan meningkatkan daya saing nasional. Salah satu kecamatan di Kabupaten Banyuasin yang pada musim hujan akses jalannya rusak parah yaitu kecamatan Tanjung Lago. Permasalahan yang terjadi di kecamatan Tanjung Lago keterbatasan 
kemampuan dari infrastruktur jalannya atau yang disebabkan lemahnya daya dukung tanah pada lapis tanah dasar (subgrade), tanahnya memiliki kohesifitas tinggi/ tanah lempung. Padahal kecamatan Tanjung Lago memiliki potensi sumber daya lahan yang besar yang belum dikelola dengan baik untuk: pertanian perkebunan peternakan dan budidaya perikanan. Saat terjadi intensitas curah hujan yang tinggi, akses jalan daerah ini rusak parah yang mana beberapa kawasannya tersebut menjadi terisolasi. Kondisi ini diperparah dengan sulitnya mendatangkan bahan timbunan seperti pasir urug, sirtu dan lainnya.

Salah satu upaya yang bisa dilakukan untuk memperbaiki daya dukung tanah adalah dengan menggunakan metode stabilisasi. Stabilisasi tanah dapat dilakukan dengan menambahkan berbagai jenis bahan stabilitator (stabilizingagent) berupa mineral maupun kimiawi (chemical) salah satunya dengan menambahkan bahan seperti semen, fly ash, kapur dan sebagainya. Stabilisasi tanah dengan penggunaan stabilizingagent juga terbukti dapat menaikan nilai California Bearing Ratio (CBR) dan juga bisa membuat sifat kembang susut tanah menjadi rendah, terbukti dari penelitian yang dilakukan yaitu: (i) penambahan campuran petrasoil dengan air, tanpa dikombinasikan dengan bahan tambah lain dapat menyebabkan kondisi tanah semakin tidak stabil (Herius et al., 2019), (ii) lama waktu pemeraman yang berpengaruh terhadap peningkatan nilai CBR terbesar adalah pada variasi penambahan kapur 15\% dengan durasi waktu pemeraman 14 hari yaitu sebesar $79,27 \%$ (Soehardi et al., 2017), (iii) penambahan kapur sebagai bahan stabilisasi tanah lempung dapat meningkatkan kepadatan dan kuat geser tanah berdasarkan nilai tegangan geser dan kohesi (Gati \& Ha, 2016), (iv) kapur dan semen adalah stabilisator yang baik untuk tanah gambut (Zambri \& Ghazaly, 2018), (v) setelah diamati bahwa jenis tanah, jenis kapur, persentase kapur dan kondisi pemulihan (waktu, suhu) meningkatkan nilai CBR secara signifikan setelah penambahan muatan kapur (Indrayani et al., 2018); (vi) Pengaruh Fly Ash terhadap nilai CBR dan sifat properties tanah (Mina \& Kusuma, 2016); (vii) Penambahan Fly Ash dan Kapur dapat meningkatkan daya dukung tahan (Indrayani, Herius, Mirza, et al., 2020; Wibawa \& Hisyam, 2015); (viii) Penambahan Kapur dan Petrasoil dapat meningkatkan nilai geser tanah lempung (Indrayani, Herius, Zeri, et al., 2020); ix) Penggunaan limbah pasir silica dan abu pasir dalam meningkatkan kekuatan tekan tanah (Gunarti et al., 2020).

Dari penelitian tersebut jelas bahwa dengan penambahan stabilizingagent, dapat memperbaiki sifat mekanik dari tanah lempung dan meningkatkan daya dukungnya. Stabilisasi tanah dengan petrasoil cukup baik dan hampir cocok untuk semua jenis tanah, akan tetapi penambahan additive petrasoil dengan air tanpa dikombinasikan dengan bahan tambah lain dapat menyebabkan kondisi tanah semakin tidak stabil (Herius et al., 2019).

Desain penelitian yang ditawarkan dipenelitian lanjutan ini ialah upaya perbaikan daya dukung tanah melalui stabilisasi kimiawi dengan berbagai variasi campuran additive petrasoil dan kapur. Tujuan yang ingin dicapai diantaranya adalah untuk memperoleh persentase campuran additive petrasoil dan kapur yang untuk stabilisasi tanah yang maksimal serta besarnya pengaruh kadar air terhadap kinerja yang campuran yang digunakan. Dengan menambahkan stabilizingagent lainnya yaitu kapur yang telah dibuktikan dalam penelitian terdahulu efektif sebagai bahan stabilisator tanah pada tanah lempung, harganya relatif murah dan hampir tersedia di setiap daerah. Dengan unsur cation $(\mathrm{Ca} 2+)$ pada unsur kapur maka dapat memberikan ikatan antar partikel yang lebih besar untuk melawan sifat mengembang susut tanah, sehingga bisa menaikan daya dukung tanah. Disamping itu mengingat harga petrasoil yang relatif cukup mahal maka cara ini juga sebagai langkah efisiensi untuk menekan biaya produksi stabilisasi tanah tersebut 


\section{METODOLOGI PENELITIAN}

\subsection{Lokasi Penelitian}

Sebelum dilakukan penentuan lokasi pengambilan sampel, maka terlebih dahulu dilakukan pengamatan secara visual untuk menentukan titik lokasi pengambilan sampel. Titik lokasi pengambilan sampel yang diambil yaitu Kecamatan Tanjung Lago, Kabupaten Banyuasin yang merupakan salah satu daerah dengan produksi padi tertinggi di wilayah Sumatera Selatan dan merupakan daerah rawa, sehingga memerlukan prasarana infrasturktur jalan untuk mengangkut hasil pertanian. Pada titik lokasi pengambilan sampel tersebut berupa tanah rawa yang dalam kondisi tanah asli. Peta lokasi dapat dilihat pada Gambar 1.

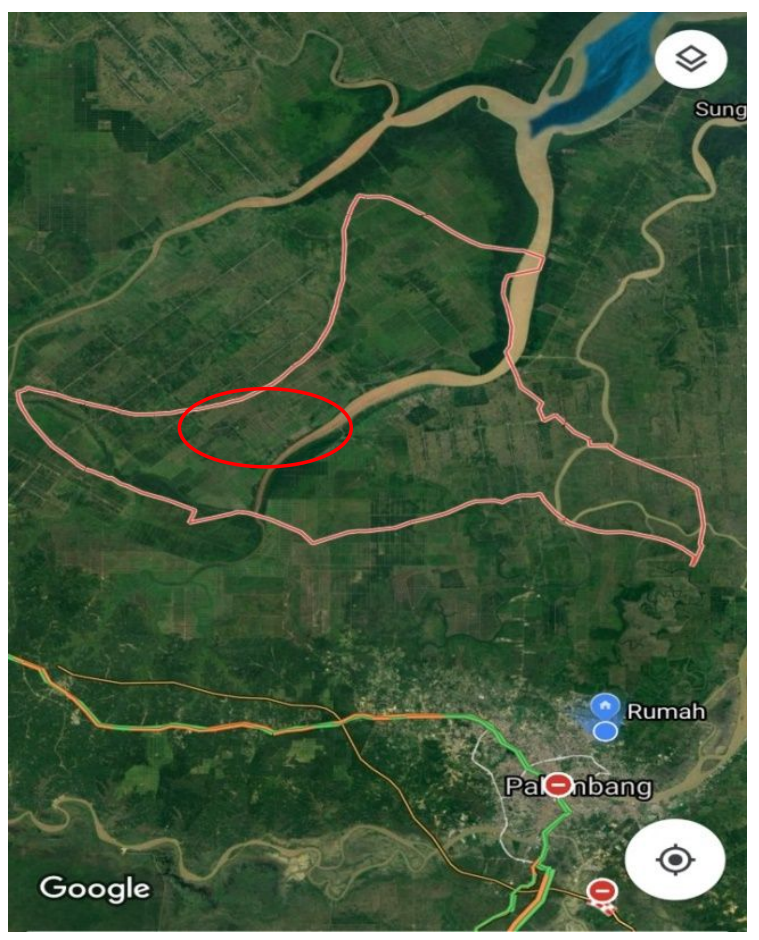

Gambar 1. Lokasi Pengambilan Sampel Tanah

\subsection{Alat dan Bahan}

Peralatan yang digunakan berupa alat-alat untuk pengujian tanah di lapangan dan laboratorium yang terdiri dari: GPS untuk menentukan lokasi pengambilan sampel tanah; 1 (satu) set alat handbor; 1 (satu) set saringan, untuk pemeriksaan agregat halus dan agregat kasar; 1 (satu) set alat pengujian batas-batas atterberg; 1 (satu) set alat pengujian indeks properties; 1 (satu) set alat pengujian hydrometer; 1 (satu) set alat pengujian pemadatan; 1 (satu) set alat pengujian cbr; timbangan digital; gelas ukur/ piknometer; cawan; oven yang dilengkapi dengan pengatur suhu; stopwatch; komputer untuk pengolahan dan analisis data; dan alat pendukung lainnya.

Bahan-bahan yang digunakan dalam penelitian ini adalah: tanah yang diambil dari daerah rawa kecamatan Tanjung Lago Kabupaten Banyuasin; bahan additive petrasoil dalam bentuk butiran-butiran kristal yang diperoleh dari supplier; kapur $\left[\mathrm{CaCO}_{3}\right]$ yang dalam bentuk serbuk yang diperoleh dari depot di wilayah kota Palembang; dan Air $\left[\mathrm{H}_{2} \mathrm{O}\right]$ menggunakan air PDAM. 


\subsection{Desain Penelitian}

Tanah yang diambil dari lokasi merupakan tanah asli dan selanjutnya akan diteliti sifat fisik dan mekanisnya. Penelitian sifat fisik tanah dilakukan guna mengidentifikasi klasifikasi jenis tanah yang digunakan.

Sedangkan penelitian sifat mekanis tanah dilakukan dalam 4 variasi, yaitu: (1) tanah asli, (2) tanah + kapur 10\% + petrasoil, (3) tanah + kapur 15\% + petrasoil. (4) tanah + kapur $20 \%$ + petrasoil.

Butiran petrasoil yang akan dicampurkan kedalam tanah harus dilarutkan kedalam air, besarnya perbandingan campuran petrasoil adalah $1 \mathrm{~kg}$ petrasoil : 1000 liter air, dimana 1 $\mathrm{kg}$ petrasoil dicampur kedalam 1000 liter air, selanjutnya diaduk sampai butiran petrasoil larut kedalam air dan didiamkan selama 1 hari sebelum campuran ini digunakan untuk mencampur tanah ataupun mencampur tanah dan kapur. Kapur yang dicampurkan dengan tanah tidak dilakukan pemeraman, Selanjutnya masing-masing benda uji di letakkan didalam kantung plastik dan diberi tanda masing-masing persantese campuran dan didiamkan selama 12 jam atau sampai jenuh. Pengujian nilai CBR dilakukan perendaman selama 4 hari untuk mendapatkan kondisi terburuk dari tanah pada saat direndam sehingga tidak dilakukan pengujian CBR tanpa rendaman.

Hasil akhir berupa perbandingan sifat mekanik tanah asli dengan sifat mekanik tanah yang distabilisasi, sehingga didapatkan besarnya pengaruh penambahan campuran bahan additive petrasoil dan kapur terhadap nilai CBR tanah. Jumlah sampel pada pengujian CBR rendaman dapat dilihat pada Tabel 1.

Tabel 1. Jumlah Sampel pada Pengujian CBR

\begin{tabular}{|c|c|c|c|c|}
\hline \multirow{2}{*}{ No. } & \multicolumn{3}{|c|}{ Komposisi Campuran } & \multirow{2}{*}{$\begin{array}{l}\text { Jumlah } \\
\text { (sampel) }\end{array}$} \\
\hline & Tanah & Persentase kapur & Petrasoil atau air & \\
\hline 1 & \multirow{5}{*}{$\begin{array}{l}\text { Tanah(@5 kg/ } \\
\text { sampel) }\end{array}$} & $\mathrm{O}$ (Tanah Asli) & Tanpa Petrasoil & 3 \\
\hline 2 & & $10 \%$ & \multirow{3}{*}{ Petrasoil } & 3 \\
\hline 3 & & $15 \%$ & & 3 \\
\hline \multirow[t]{2}{*}{4} & & $20 \%$ & & 3 \\
\hline & & & Total Sampel & 18 \\
\hline
\end{tabular}

\subsection{Tahapan Penelitian dan Analisa Data}

Tahapan-tahapan yang dilakukan pada penelitian ini adalah: (i) persiapan meliputi kajian literatur dan survei lokasi pengambilan sampel, (ii) pengambilan sampel tanah, persiapan bahan additive petrasoil dan kapur, dan persiapan alat-alat pengujian, (iii) pengujian sifat fisik tanah melalui pengujian indeks properties, (iv) pengujian sifat mekanis tanah meliputi pengujian pemadatan dan pengujian CBR dengan rendaman selama 4 hari, (v) pengolahan dan analisis data, (vi) penarikan kesimpulan yang mengacu pada tujuan penelitian. Keseluruhan pengujian dan analisa yang dilakukan mengacu pada pedoman ASTM dan SNI.

\section{HASIL DAN PEMBAHASAN}

Dalam penelitian ini pengujian indeks propertis, batas atterberg dan analisa saringan menggunakan sampel tanah asli dan air PDAM. Sementara untuk pengujian pemadatan dan kekuatan geser menggunakan petrasoil dengan perbandingan campuran petrasoil : air $=1$ $\mathrm{kg}$ : 1000 liter. Campuran terhadap keseluruhan bahan tambah dilakukan dalam 4 variasi, 
yaitu: (i) tanah + air, (ii) tanah + kapur10\% + petrasoil; (iii) tanah + kapur 15\% + petrasoil; (iv) tanah + kapur $20 \%+$ petrasoil.

Berbagai variasi campuran tanah dengan bahan tambah berupa bahan additive petrasoil dan kapur mempunyai perilaku yang berbeda, tergantung persentase variasi campurannya. Dalam penelitian ini penambahan kapur yang digunakan adalah sebesar 10\% 15\% dan $20 \%$. Pengujian yang dilakukan terhadap campuran tanah dengan bahan tambah berupa bahan additive petrasoil dan kapur ini terdiri dari pengujian sifat fisik dan sifat mekanis tanah.

\subsection{Pengujian Sifat Fisik Tanah}

Pengujian sifat fisik tanah terdiri dari pengujian berat jenis tanah normal, pengujian batasbatas atterberg, analisa saringan, dan pengujian hidrometer. Hasil pengujian-pengujian ini dapat dilihat pada Tabel 2.

Menurut American of State Highway and Transportation Officials Clasification (AASHTO) tanah ini tergolong dalam klasifikasi tanah lempung (AASHTO, 1998).

Tabel 2. Hasil Pengujian Sifat Fisik Tanah

\begin{tabular}{llll}
\hline No. & Variabel & Hasil & Satuan \\
\hline 1 & SpecificGravity $(G S)$ & 2,60 & - \\
\hline 2 & Lolos Saringan No. 4 $(4.75 \mathrm{~mm})$ & 94,76 & $\%$ \\
\hline 3 & Lolos Saringan No. 200 $(0.075 \mathrm{~mm})$ & 53,74 & $\%$ \\
\hline 4 & Batas Cair $(L L)$ & 63,28 & $\%$ \\
\hline 5 & Batas Plastis $(P L)$ & 42,95 & $\%$ \\
\hline 6 & Indeks Plastisitas (IP) & 20,32 & $\%$ \\
\hline 7 & Klasifikasi Tanah (USCS) & $\mathrm{MH}$ & - \\
\hline 8 & Klasifikasi Tanah $(A A S H T O)$ & $\mathrm{A}-5$ & - \\
\hline
\end{tabular}

\subsection{Pengujian Pemadatan}

Kadar air optimum dari hasil pengujian pemadatan terhadap 4 variasi campuran adalah $15,76 \%$ untuk tanah asli; $24,27 \%$ pada tanah + petrasoil + kapur $10 \% ; 21,97 \%$ untuk tanah + petrasoil + kapur $15 \%$; dan 20,96\% untuk tanah + petrasoil + kapur $20 \%$. Hasil ini dapat dilihat pada grafik Gambar 2.

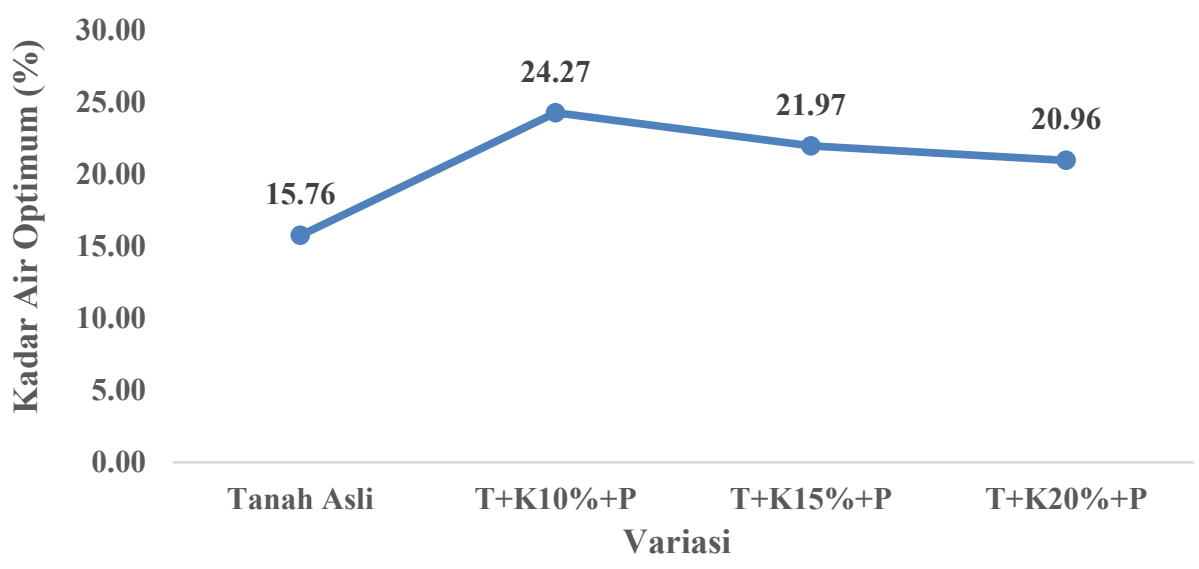

Gambar 2. Grafik Hasil Pengujian Kadar Air Optimum 
Rata-rata tanah dengan campuran kapur memiliki kadar air diatas 20\%, sedangkan tanah asli memiliki kadar air 15,76\%, dan kadar air optimum berada pada variasi campuran tanah + petrasoil + kapur $10 \%$.

Sedangkan berat isi kering dari hasil pengujian pemadatan terhadap 4 variasi campuran adalah $1,286 \mathrm{gr} / \mathrm{cm}^{3}$ untuk tanah asli; $1,210 \mathrm{gr} / \mathrm{cm}^{3}$ pada tanah + petrasoil + kapur $10 \% ; 1,250 \mathrm{gr} / \mathrm{cm}^{3}$ untuk tanah + petrasoil + kapur 15\%; dan 1,307 gr/ $/ \mathrm{cm}^{3}$ untuk tanah + petrasoil + kapur 20\%. Hasil ini dapat dilihat pada grafik Gambar 3.

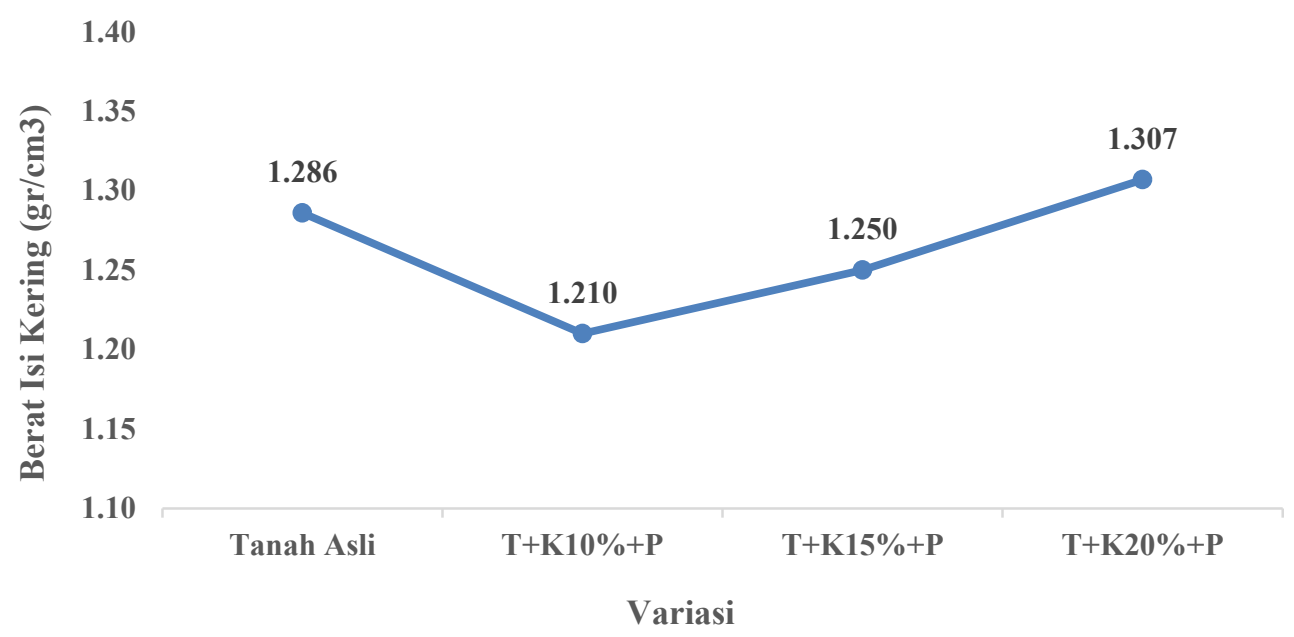

Gambar 3. Grafik Hasil Pengujian Berat Isi Kering

Grafik pada Gambar 3 menunjukkan bahwa berat isi kering optimum berada pada variasi campuran tanah + air + kapur $20 \%$ yaitu sebesar $1,307 \mathrm{gr} / \mathrm{cm}^{3}$ dan berat isi kering terendah pada campuran tanah + air + kapur $10 \%$ yaitu sebesar $1,210 \mathrm{gr} / \mathrm{cm}^{3}$

\subsection{Pengujian Nilai CBR}

Pengujian nilai CBR dilakukan untuk mendapatkan nilai daya dukung tanah dalam keadaan padat maksimum. Hasil pengujian CBR terhadap 4 variasi campuran adalah $1,55 \%$ untuk tanah asli; $2,18 \%$ pada tanah + petrasoil + kapur $10 \% ; 5,41 \%$ untuk tanah + petrasoil + kapur $15 \%$; dan 7,88 \% untuk tanah + petrasoil + kapur $20 \%$. Hasil ini dapat dilihat pada grafik Gambar 4. 


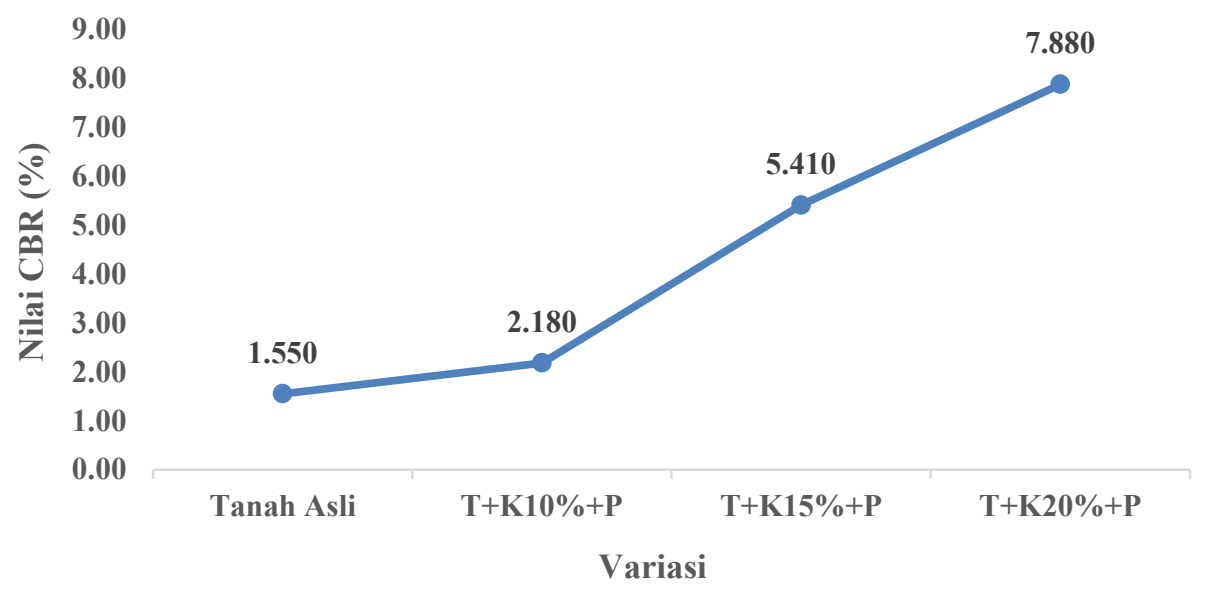

Gambar 4. Grafik Nilai CBR Rendaman

Nilai CBR rendaman pada tanah asli sebesar 1,55\% dan mengalami peningkatan dengan adanya penambahan kapur dan petrasoil. Semakin banyak penambahan kapur maka nilai CBR semakin meningkat. Nilai CBR tertinggi pada campuran tanah + petrasoil + kapur $20 \%$ yaitu sebesar $7,88 \%$.

Dari hasil pengujian CBR rendaman selama 4 hari dapat disimpulkan bahwa semakin banyak penambahan persentase petrasoil dan kapur maka nilai CBR rencaman akan mengalami peningkatan. Peningkatan nilai CBR perendaman disebabkan adanya pencampuran akibat penambahan petrsaoil dan kapur. Pencampuran ini menyebabkan penggumpalan dan penyelimutan dengan adanya peningkatan daya ikat antar butiran. Dengan meningkatnya ikatan antar butiran, maka kemampuan daya dukung tanah akan meningkat, selain itu rongga-rongga pori yang telah ada sebagian akan terisi petrasoil dan kapur, sehingga butiran tidak mudah hancur atau berubah bentuk karena pengaruh air.

\section{KESIMPULAN}

Penambahan petrasoil dan kapur sebagai bahan tambah pada tanah rawa dengan klasifikasi tanah lempung dapat meningkatkan nilai CBR tanah dari 1,55\% pada keadaan tanah asli menjadi $7,88 \%$ pada kondisi tanah yang distabilisasi menggunakan petrasoil dan kapur $20 \%$.

\section{UCAPAN TERIMAKASIH}

Ucapan terimakasih kami sampaikan kepada Politeknik Negeri Sriwijaya atas pendanaan yang telah diberikan pada Skema Penelitian Kerjasama Dosen-Mahasiswa dan pemberian ijin penggunaan fasilitas laboratorium uji tanah Jurusan Teknik Sipil.

\section{DAFTAR PUSTAKA}

AASHTO. (1998). Standard Specification for Transportation Materials and Methods of Sampling and Testing Part I: Specification. 19th edition. American Association of State Highway and Trasportation Officials, Washington D C.

Gati, S. U., \& Ha, A. H. (2016). Analisis Pemanfaatan Batu kapur Sebagai Bahan Stabilisasi Tanah Lempung Ditinjau dari Kuat Geser. Prosiding SNSTT IV, Institut Teknologi Adhi Tama, Surabaya.

Gunarti, A. S. S., Nuryati, S., Muttaqin, P. A., \& Raharja, I. (2020). Unconfined compression strength of soil using silica sand waste and dust sand foundry as a stabilizer. Journal of Physics: Conference Series, 1517(1), 12028. 
Herius, A., Indrayani, I., Hasan, A., \& Mirza, A. (2019). Addition Effect of Petrasoil Additive Material on CBR Value of Soil in Swamp Areas. Indonesian Journal of Environmental Management and Sustainability, 3(2), 67-70.

Indrayani, I., Herius, A., Hasan, A., \& Mirza, A. (2018). Comparison Analysis of CBR Value Enhancement of Soil Type in Swamp Area by Addition of Fly Ash. Science and Technology Indonesia, 3(2), 73-76.

Indrayani, I., Herius, A., Mirza, A., Saputra, D., \& Fadil, A. M. (2020). Campuran Fly Ash dan Petrasoil dalam Peningkatan Daya Dukung Tanah. BENTANG: Jurnal Teoritis Dan Terapan Bidang Rekayasa Sipil, 8(2), 99-104.

Indrayani, I., Herius, A., Zeri, P. N., \& Fernando, N. (2020). Analisis Kuat Geser Tanah Lempung menggunakan Kapur dan Petrasoil. Jurnal Teknologi Terpadu Politeknik Negeri Balikpapan, $8(1), 64-68$.

Mina, E., \& Kusuma, R. I. (2016). Pengaruh Fly Ash Terhadap Nilai Cbr Dan Sifat-Sifat Propertis Tanah Studi Kasus: Jalan Raya Bojonegara Km 19 Serang Banten. Fondasi: Jurnal Teknik Sipil, $5(2)$.

Soehardi, F., Lubis, F., \& Putri, L. D. (2017). Stabilisasi Tanah Dengan Variasi Penambahan Kapur dan Waktu Pemeraman. Konferensi Nasonal Teknik Sipil Dan Perencanaan (KN-TSP), 59-66.

Wibawa, A., \& Hisyam, E. S. (2015). Pengaruh Penambahan Limbah Gypsum terhadap Nilai Kuat Geser Tanah Lempung. FROPIL (Forum Profesional Teknik Sipil), 3(2), 65-71.

Zambri, N. M., \& Ghazaly, Z. M. (2018). Peat Soil Stabilization using Lime and Cement. E3S Web of Conferences, 34, 1034. 